\title{
South Asia in the 21st Century Global Order: Problems, Promises and Positioning
}

\author{
Munim Kumar Barai*
}

\begin{abstract}
The world is passing through a crossroad as the multipolarity in the world order is now a distinctive possibility in the 21st Century. In that emergence, the center of global economic gravity is seemingly moving toward the Asia Pacific zone. The USA, the sole superpower in the present order, is increasingly facing challenges from China, Russia and other rising powers like India and Brazil. The success of the EU as an economic and political experiment will determine its role in the future context. This paper tries to assess a place for South Asia as a unit in the 21 century global order and finds a number of persisting problems like poverty, population, corruption, poor quality of education, disruptive political discourse, weak democratic governance, indiscipline, religious and ethnic tensions that impede their future progress. At the same time, the paper sees immense future potentials for South with their growing economies, demographics, diversity, diasporas, IT knowledge, and dynamism. However, the Indo-centric geographic identity of South Asia is both a problem as well as a promise. This paper argues that to reap the benefits of commonality, they need to approach their future collectively and cohesively.
\end{abstract}

Keywords: South Asia, Population, Corruption, Governance.

\subsection{Introduction}

In the twentieth century, the world saw the emergence of a bi-polar world at the end of Second World War in 1945. On the one hand, the United States of America (USA) led a pole with democracy as a political system and capitalism as a dominant social and economic way of life. On the other side, the erstwhile Union of Soviet Socialist Republics (USSR) gave lead a pole with socialism as economic and social ideology to run the state and to govern people.

*Professor of Finance, College of International Management, Ritsumeikan Asia Pacific University, Japan. 
That also came to be known as the rule of the proletariat. Along with the ideological bases, both the powers depended on three ingredients to establish their sphere of influence on the order - the economic power, the military power and the technology power. But the bi-polarity of the world ended in 1991 with the sudden demise of the USSR and we saw the world entering into a phase of unipolarity of the order, the US remaining to be the sole superpower. But within the span of twenty years and at the beginning of the 21st century, the world is going through unprecedented changes in the power and hence also in the global order. In the newer context, we are not only experiencing the rise of few other economic poles, absorbing the economic upheavals still emerging from the financial crisis of 2008, but also are threatening the US hegemon in the order. The world is indeed passing through a transition where multipolarity in the order is now a distinct possibility in the 21 st Century. With the economic and military rise of China and a potential rise of India, the center of power gravity is slowly and surely moving towards Asia.

In the changing context of the global order, what is the promise of South Asia to be a part of one of the poles of importance? Does the region really hold any promise in the future to be counted importantly in the emerging world order? What needs to be done to transform their promise into reality? Can the countries of the region overcome the barriers to work together for the collective betterment of their people?

These are some key questions that need to be addressed seriously in assessing the future of South Asia. At the same time, we should have a clear idea of the physical space that we can consider as South Asia as a potential cohesive regional unit. South Asia is situated in the southern region of the Asian continent, comprising the subHimalayan countries. But a broader view of South Asia also includes the adjoining countries to the west (Iran) and the east (Myanmar) (Ghosh, 1989; McLeod, 2002). On the south, South Asia is bounded by the Indian Ocean and on land (clockwise, from the west) by West Asia, Central Asia, East Asia, and Southeast Asia. Various other sources have drawn the boundary of South Asia as well. For example, the United Nations' definition of South Asia's geographical region includes the countries of Afghanistan, Bangladesh, Bhutan, India, Iran, Maldives, Nepal, Pakistan and Sri Lanka (United Nations Statistics Division, 2013).

In 1985, seven South Asian countries formed the regional bloc "South Asian Association for Regional Cooperation" (SAARC). They are - Bangladesh, Bhutan, India, the Maldives, Nepal, Pakistan and Sri Lanka. Afghanistan was included as the eighth member of the group in 2006. Now SAARC includes three independent countries that were not under the British rule - Nepal, Bhutan, and Afghanistan. But it excludes one, Myanmar, which was also part of the British Raj. So the question arises whether 
Myanmar should be treated as a member of South Asia or not. As an ASEAN member Myanmar, of course, is perceived to be a South East Asian nation. But considering its physical congruence, cultural affinity and historical linkages with countries in South Asia, Myanmar looks to be a constituent of the region. The inclusion of Myanmar adds strategic depth to the South Asian region too.

Historically, South Asia of our definition was one of the most developed and civilized regions in the world. Two of the greatest religions, Hinduism and Buddhism, originated from this part. This region also housed the great Harappa and Mahenjo Daro civilizations "which, prima facie, accorded them a maturity and experience that many other nations and peoples could not boast of "(Cabraal, 2002). Even today, the South Asians speak of their past greatness in awe and eulogize the common past achievements. Cabraal lauds, "--the lands and peoples living in the areas that are today described as the South Asian region, were linked in many ways. These links were inter alia, cultural, religious, as well as military and language based. Over the centuries, these links, connections, and similarities have continued to exist and grow. Although some disagreements have surfaced amongst these countries at various times, these nations and their peoples have continued, and continue to remain, inexorably associated with one another."

In contrast to that common heritage, presently there are many areas where the South Asian countries are divided, their mutual distrust high and political discourse different. Therefore, it makes sense to analyse how the region can place itself in a changing global order, based on their present and future strengths and weakness. Question is - will South Asia hold together a shared desire to influence the future order or just will remain happy with the second-fiddle role it has played since the mid of 1940s after most of the countries here got independence? More precisely, given the multiple divides and fault lines at the State and societal levels, do they have a common future as a region? Can they manage their challenges and march ahead to shape a better future for their people and influence the developments in Asia and other parts of the world in the 21 st century?

The objective of the paper, however, is to juxtapose South Asia as a single entity vis-à-vis others in the $21^{\text {st }}$ century to find a place for the region in the emerging order. That is why, we make an attempt to draw a common picture for South Asia by assessing some of its weaknesses and strengths that the region inherited or gathered for a possible positioning for the coming days. The assessment here, though, has been influenced by a belief that South Asia could be an effective player in the world order as the economic gravity of the world is visibly shifting toward Asia. However, in the search for a collective and common future, it is better not to focus much on "shared 
4 | FOCUS: Journal of International Business, Vol. 2, Issue 1

past" of culture and history. Because, that "shared past is disputed and full of violence, partition and horror stories, which can be easily manipulated. True, we should understand the past, but we should also ensure that it does not affect our future, because some of have misread it " (Chandran, 2013).

The paper has five more parts devoted to discussing the place of South Asia in the 21st-century global order. Part two tries to give a sketch of the emerging world order in this century. Part three discusses the persisting problems of South Asia that they are facing now and need to overcome for a bright future. Part four identities the promises of South Asia that may help them to come out a zone of economic and political vibrancy in the medium to long term. But achieving an important place in the global order is not automatic, and the region as a whole has to position itself for a better future. Part five deals with some positing strategies for the future. Part six concludes the paper.

\subsection{World Order in the 21st Century - A Theoretical Account}

Till date, those powers that dominated the history of civilization and empire building had one thing in common - the military power. With a few exceptions, most of the empires used their military might to subjugate others politically and economically. Sometimes the force was used for purely plundering of others resources. Though Europe saw the birth and inception of nation-statehood for the creation of states, those states also played a role in the modern phase of empire building. Their effort went through a dimensional change with the onset of the second industrial revolution in the eighteenth century. Technology - with economic, military and civilian uses - led some early industrialised European powers to spread their empires by colonizing small and big kingdoms all over the world. This brought changes in their political and economic fortune as well. There was no such idea of world order, as we mean today, as most parts of the world were divided among some colonial powers. But the First World War (191418) in the heart of Europe made the way for the idea of world order to get a formal institutional shape. That was realized through the creation of the League of Nations in 1919 under the Treaty of Versailles "to promote international cooperation and to achieve peace and security"(UN, 2015).

With the passage of time, we see maturing of the idea and efforts of some of the states wanted to influence and dominate the twenty-century world order by a combination of some their powers. But three powers formed the backbone of their domination - the economic power, military power and technology power. Sometimes, in the name of establishing rules of law, all these factors were used on a concerted basis. Notably, before World War II, an accumulation of all these powers happened to be in the 
hands of the US and few west European nations. But former Soviet Union emerged as a decisive and powerful force in the WWII to liberate the Eastern Europe. With the rise of USSR, the ideology of socialism also became an alternate economic and political system and attracted believers around the world. That added a fourth power to gain importance to influence the world order - the ideological power.

An analysis of the world order in the 20th century shows that the decline of British Empire had happened not only because of its loss of the colony based economic fortune in the mid of the past century, but also as a consequence of the transfer of technological and ideological weights of capitalism and democracy to the other side of the Atlantic. That is; the USA rose to become a gigantic power with a combination of all these elements of a great empire. However, the former USSR emerged as a counterbalancing force to the US with its excellence as a mighty fighting power as well as for the appeal of Marxist ideology based on the philosophy of the power of the proletariat. However, the challenge to the US-dominated world order by the USSR did not last long. This was partly because of the failure of USSR to give timely push and dynamism to its economic ideology as a leading counter-bloc to democracy and capitalism. The intervention in Afghanistan also turned out to be very costly for it. Sure enough, with the demise of USSR in the 1991, the USA has emerged as the most powerful "Empire" that the human civilization has seen so far.

Since WWII to now, the US wanted to increase and consolidate its hold on the world order by various strategic institutions and organizations. The creation of the Breton Woods institutions, IMF and IBRD (World Bank), in 1944 and GATT in 1947 (converted to WTO in 1995) gave strong platforms to exert its influence on economic and political spheres in the world. The US domination on the twin institutions may be understood from this statement, "The liberal ideal of equal partnership between participating nation-states was wonderful, but in reality, the headquarters of both organizations have been located in Washington, and most of the privileges in the two organizations including voting power have been monopolized by the United States for 70 years: a surprisingly long duration" (Nakayma, 2014).

On the other hand, the North Atlantic Treaty Organization (NATO) has brought a sense of military protection to a large number of countries. The US also tried to widen and deepen its influence by queuing of other lesser economic powers in the capitalist bloc through G-7. In the US Order, a profound clout has been created for its dollar; first, by its acceptance as the unit of currency for determining fixed exchange rate in 1944 and then by a successful promotion of dollar as the global currency of reserve and trade after the collapse of the fixed exchange rate in 1974. A plethora of other supporting institutions and NGOs were created to check or word off the challenges any potential 
ideologies or political players that at the same time promoted American values and western culture. The most interesting development, of late, was the use of MNCs as the flag bearers of corporate capitalism. The slogan of liberalisation and globalisation simply smoothened the operations of the MNCs to become viable manipulating tools for maintaining the impact on the order. But the sudden rise of China in the global arena and its growing economic and military prowess seem to have posed a greater challenge to the existing global order. Is the rise of China giving an indication to the coming order in the 21 st century? Is China going to fill the vacuum left by the demise of Soviet Union? Or, is something else waiting for the people of the world with surprises? Looking at the trend, it now seems that the world is passing through a crossroad in the order as some players of the game are changing.

A point to ponder is that the direction of a new world order might have been set by the financial crisis of 2008 as well. This crisis is unique in the sense that it started from a single sector of a single economy to spread and affect the whole world ${ }^{1}$. It also dawned on the reality that it may need the spark of a single event that could open the hollow of an existing system, or that can lead to the downfall of a super power and the current order too. The crisis in 2008 has also revealed some of the US economic and political weaknesses. Time to time in the past, warmongering and overstretching of the power had led many empires to demise. In the US case, both these elements of demise are present. The cost of its external interventions for "establishing the rules of law of the order," it assumed to lead was high. Moreover, excessive dependency on the private corporations that have an insatiable love for money and the subsequent demise of some of them put a spanner in the power of the USA-led world order. The scope for a debate on the rise of China has also widened because of the relative decline of US due to the crisis. The question is - will the crisis of 2008 be remembered as the beginning of the end of US supremacy and the world order it established and dominated for about a century? Transform, a European Network for Alternative Thinking and Dialogue, (2012) in a statement says, "The USA is losing global influence, although it had seen itself, after the end of the Cold War, as the new hegemon in a unipolar world. Asia, especially China, is seen as a keen contender for the position of a hegemon. The European Union, despite its current crises, sees itself as a global player; the Eurasian land mass is taking on a new shape; Brazil and India have joined in the game. The hegemons seem to have had their day in global relations and been succeeded by a multipolarity."

There is every likelihood that the economic growth pole in the future will not remain limited to one country or two. Likewise, the technology and military powers are also showing diverse pockets of gravitation. In the emerging context, it remains to be seen what replaces the ideological power as the fourth pillar of the 21 st-century global 
order. The fact is, democracy and capitalism have outclassed other comparable challenging ideologies in the twentieth century. Without a competing ideological power is sight, soft power may take an increasing role to shape the order in the 21 st century. Further, we may be passing through a transitional period for an order to get a stable shape. It remains to be seen how long this will take. It is plausible to think that the transition will be peaceful, but it can be turbulent, as well.

\subsection{Persisting Problems in South Asia}

The problems in the South Asian countries are many and well known. But let us deal with some of the important gray areas first. On their way to becoming a meaningful and contributory entity in the 21st-century world order, the South Asian countries have to overcome some of the problems that have been here for quite a long time. These problems are well known and nearly similar to all of them. Also, the issues identified here may not make an exclusive list of the problems South Asia is facing and in all possibility they will continue to dodge the region for some time. Keeping this limitation in mind, I'm going to get to more fundamental problems (Table 1).

Table 1: Some Basic Statistics of South Asia, 2012

\begin{tabular}{|c|c|c|c|c|c|c|}
\hline \multirow[b]{2}{*}{ Country } & \multirow[b]{2}{*}{$\begin{array}{l}\text { Surface Area } \\
\left(\text { Thou. } \mathrm{km}^{2}\right)\end{array}$} & \multirow[b]{2}{*}{$\begin{array}{l}\text { Population } \\
\text { (millions) }\end{array}$} & \multirow[b]{2}{*}{$\begin{array}{l}\text { Density } \\
\text { Per Km² }\end{array}$} & \multicolumn{2}{|c|}{ National Income } & \multirow[b]{2}{*}{$\begin{array}{l}\% \text { GDP Growth } \\
(2011-12)\end{array}$} \\
\hline & & & & $\begin{array}{l}\text { Gross } \\
(\$ \mathrm{bn})\end{array}$ & $\begin{array}{l}\text { Per capita } \\
\operatorname{PPP}(\$)\end{array}$ & \\
\hline Afghanistan & 652.2 & 29.9 & 46 & 20.4 & 1,560 & 14.4 \\
\hline Bangladesh & 144.0 & 154.7 & 1,188 & 129.3 & 2,030 & 6.2 \\
\hline Bhutan & 38.4 & 0.7 & 19 & 1.8 & 6,200 & 9.4 \\
\hline India & $3,287.3$ & $1,236.7$ & 416 & $1,913.2$ & 3,820 & 4.7 \\
\hline Maldives & 0.3 & 0.3 & 1,128 & 1.9 & 7,560 & 3.4 \\
\hline Nepal & 147.2 & 27.5 & 192 & 19.2 & 1,470 & 4.5 \\
\hline Pakistan & 796.1 & 179.2 & 232 & 225.1 & 2,880 & 4.0 \\
\hline Sri Lanka & 65.6 & 20.3 & 324 & 59.3 & 6,030 & 6.4 \\
\hline Sub-Total & $5,131.1$ & 1649.3 & & $2,370.2$ & & \\
\hline Myanmar & 676.6 & 52.8 & 81 & $53.1^{\mathrm{a}}$ & $1,700^{\mathrm{b}}$ & $6.4^{\mathrm{b}}$ \\
\hline Total & $5,807.7$ & $1,702.1$ & & $2,423.3$ & & \\
\hline
\end{tabular}


Poverty: The distinction here is obvious: South Asia houses the biggest number of poor people in the world and is the 2nd poorest region after Sub-Saharan Africa. Taken Myanmar into the South Asian fold, the scenario gets even worse. A World Bank Study says that South Asia is home to half of the world'spoor. About 29 percent of Indians, 33 percent of Pakistanis and 42 per cent of Nepalese live below the poverty line (also in Pattanaik, 2011: p. xix). Although Bangladesh has shown remarkable progress in reducing poverty in recent time, still more than 31 percent of its people live under the line of poverty. According to UN's Multidimensional Poverty Index, just over a quarter of the world's MPI poor people live in Africa, while a half lives in South Asia. The study also found there are more poor people in eight Indian states than in the 26 poorest African countries. According to the index, 55 percent of people in South Asia are MPIpoor and in sub-Saharan Africa, 64.5 percent of people is MPI-poor. Both figures are higher than those considered extreme income-poor - living on less than \$US1.25 per day (Alkire and Santosh, 2010). According to a 2008 World Bank estimates, Pakistan was most exposed to poverty risks among 43 countries. Its poverty rate jumped from 23.9 per cent to 37.5 per cent in three years from 2005 (Dhakan, 2014). However, Sri Lanka, the Maldives, and tiny Bhutan have a better position than their regional partners in this regard.

Population: South Asia includes some of the most populous countries, and it is also the most densely populated region in the world. Taken individually, India is the 2 nd most populated country, Pakistan and Bangladesh are 6th and 8th, respectively. The SAARC8 plus Myanmar have an area of 5.8 million $\mathrm{km}^{2}$, and a population over 1,702 million which is more than 23.7 percent of the estimated 7.2 billion people in the world. India alone constitutes 1.236 billion people or more than 17 percent of the world total (Table 1). With little basic hard and soft infrastructural facilities, the size of the population is proving to be a big burden.

Corruption: Corruption has become most pressing economic and social problem in the region. Cabraal (2002) writes, "Everyday, instance where a person has gained an unfair advantage over another in business, employment, education, sports, tenders, or almost anything, and instances where rules have been bent, changed or stretched, to give undue advantage to certain selected persons, is heard of. Corrupt tenders, fraudulent contracts, wrongful promotions, undue delays, political victimizations, etc., are also the order of the day." Alarmingly, the system in all the countries is getting corrupted in the process. Allow corruption as a normal ingredient of the society could only bring a dangerous future. 
This is reflected in the Corruption Perception Index (CPI) prepared by the Transparency International, a Berlin-based organization. From 2001, Bangladesh headed the list of most corrupt countries for four consecutive times. Since then it has improved its rank and Afghanistan now tops the list of most corrupt countries among the SAARC Countries. To match with its future promise, it needs a lot to do in the area of corruption as it still ranks quite low in the CPI list. ${ }^{3}$

Disruptive Political Discourse and Indiscipline: Frequent disagreements on various intra-state issues related to economic, political, religious, racial, and majority-minority groups disrupt the democracy and increase pressure in the region. The civil war in Sri Lanka, recent political strive in the Maldives are also examples of indiscipline and disruption of political discourse. Countries in South Asia also face political instability because of the changes in the nature of governments, with the exception of India. In Pakistan, with its sad history of false dawns and dashed hopes, democracy is yet to get accepted in the public domain. The military ruled half of the life of Pakistan's existence from 1947. Run for democracy was disrupted by the power-loving generals so many times. Democratic values are yet to gain strong ground there. Bangladesh, on its part, has experienced changes of government regularly since 1991. But after every five-year, a cycle of violence and disruption of normal political life has become a standard. Sri Lanka is now seeing a stable government after a long time of internal turbulence. Nepal is yet to find a stable path for its transition from the Monarchy to multi-party democracy. Recently, the Maldives is becoming a restive democracy. A relatively calm Bhutan has an opposite counterpart called Afghanistan that is seeing a bloody struggle with internal and external dimensions. But the inter-state rivalry and tension, due to some created causes and some inherited historical baggage, are helping create distrust between the states in the region. The partition in 1947 led to the creation of India and Pakistan as sovereign states along the religious line. "The wounds of partition are yet to heal in South Asia and the post- colonial nation-states in the region have carefully nurtured the concept of the 'other' in the process of creating exclusive national identities that justify their existence as separate nations" (Pattanaik, 2011: p. xx). This resulted in the massive displacement of people and conflict between them. The 1971 Indian intervention for the Bengalis of the then East Pakistan to get independence furthered the legacy of partition. So the historical baggage and legacies make it sometimes difficult, if not impossible, to pursue a closer regional integration among the South Asian constituents.

Indo-centric Physiology: The giant presence of India at the heart of South Asia is sometimes perceived to be a problem. Extension of the Cold War in the region had made the problem acute. Now look at some of the statistics. India constitutes 65 percent of the total physical area of present SAARC, sharing a physical border with all the countries in 
the region except Afghanistan and the Maldives. It makes 75 percent of the region's population or around three times the combined. Thus the size of the population, geographic area and economy makes India the formidable population of seven other SAARC countries. India's economy is 80 percent of the regional total followed by Pakistan (10 per cent) and Bangladesh ( 7 percent) and it is getting bigger power at the heart of the region. India is also the most populous democracy in the world. Its military power is larger than the total of others (except probably the Pakistan's stockpile of nukes). There are some events of the recent past that make a block of powerful people in South Asia uncomfortable with India. For example, Indian cooperation in the independence of Bangladesh has remained an irritant between India and Pakistan for long. In addition, the physical contiguousness of India with most of the countries has made it prone to getting involved in frictions of economic, social and political nature. So, sometimes instead of being a solution, India becomes part of the problem.

Rise of Ethnic and Religious Divide: Vacating or surrendering social, political and public space to people with a religious agenda seems to have gained ground in South Asia, as well. Present Egypt is the best example of consequences of such acceding of space to such groups. Unfortunately, the partition of the Indian Subcontinent on religious lines rooted the first major victory for many of them. Since then there was always a helping hand for the religious bogey from the ruling military in Pakistan. The generals were more than willing to accommodate them to create their support base as they lacked popular support. India has also seen the rise of religious groups too. Bangladesh and Sri Lanka have experienced a rise of ethnic and religious sentiments at different stages of their existence. But in the age of free flow of information and globalization, cross-border repercussions of any such domestic incident are quite possible. The developments in Afghanistan and their spillovers in Pakistan and vice versa have the potential to affect the entire region in the coming days. "Exacerbation of conflict in some countries, inability of countries to deal with violence politically and accommodation of minority rights have created the conditions for a perpetuation of violence" (Pattanaik, 2011: p. xviii). Moreover, "The social and religious divides, along with strains of violent philosophy from outside the region, is likely to be the greatest threat to South Asia's common future. A region deeply divided over ethnic and religious differences, expressed violently, will not be able to prosper" (Chandran, 2013). Importantly, we should not miss the economic fallouts of such development. The best case example in this regard is Pakistan. Its present economic woes and administrative anarchy are attributed to the overarching influence of the military and Islamic extremism. 
Education: Poverty is also rampant, so is illiteracy. There are, for example, more illiterate women in India than in the entire continent of Africa! Furthermore, the women population seem to have remained at the furthest end of poverty margin in all the countries. However, the deadly combination of over-population and poverty could be a breeding ground for many of the social evils. Along with different intervention measures, education could serve as a weapon to fight poverty. Unfortunately, South Asia lacks that educational infrastructure too. A look at Malaysian approach to economic development at the initial phase reveals that it wanted to impart vocational education to its pupil first for making them productive. In South Asia, higher education seems to have grown disproportionately than mass vocational and technical education.

Weak Democratic Governance- Poor Response to Problems: Most of the problems in South Asia requires cohesive and carefully conceived responses based on sound principles and practices of good governance. But sadly that has not happened. The scorecard of good and democratic governance is not pleasing. Ad-hocism and reactive approach have dominated the governance model. Clearly, many of the problems in the societies here could be explained from poor governance angle, as well. "In addition to corruption, low productivity levels, almost non-existent public sector accountability, dismal governance structures in government, blatant and unconscionable family dandyism, a deplorable regional work ethic, shockingly low levels of ethnic and religious tolerance, wide-spread political interference, non-responsive education systems which are far removed from the economic needs of the respective countries, undue emphasis on caste and religious issues, are but some of the common governance problems in the region" (Cabraal, 2002).

The problems do not exhaust here. Even if we look at the regional level cooperation in SAARC or other regional initiatives, then we find little progress in this regard. The spirit of regional integration has become hostage to suspicion and distrust. This has something to do with their colonial past and "divide and rule" strategy of the colonial masters used to keep them subjugated.

\subsection{Promises of a Brighter Future for South Asia}

The basic premise of global order in the 21st century is that Asia will drive growth and development though some caveats should hold true but not undermine the premise. Similarly, despite all the intra-state and inter-states difficulties in the region, South Asia should form an important part of the global order that is experiencing a shift in the locus of power. With a vast population, increasing economic promise and Indocentric geography of the region, South Asia makes a bona fide contender to be in the 
spotlight of such a shift. The presence of some other important elements that may form the basis for building a brighter common future makes the promise of South Asia brighter.

Demography, Dynamism, Diaspora and Diversity: Anyone deals with developmental issues knows the importance of four Ds - Demography, Dynamism, Diaspora and Diversity - for a country or region. South Asia is heavily blessed with all these Delements at the moment. When Japan has aged, the Western Europe and China are aging, then South Asia promises to have an excellent demographic composition for a long foreseeable future. The number of youth in South Asia will increase by 12.1 million or from 27 per cent to 29 per cent by 2015 (Pattanaik, 2011). However, this may be doubleedged sword if enough employment provisions may not be created for the youths joining the pool of population. ${ }^{2}$ So, giving priority to generate employment for them could lay the first step for the future.

Again, the fittest survives because of "Dynamism," the ability to adjust to the changing context. As Cabraal (2002) puts it, "the people's intense thirst for knowledge and education, their ability to adapt to changing situations, their resilience in the face of great hardships, their relatively high intellectual ability, their somewhat easy going nature, their inherent respect for elders and authority, and their deep sense of patriotism, could all be considered as strengths that the people of the (South Asian) region possess. All in all, it could be said that the countries in the area have been limping along trying to find solutions to their problems --- using these strengths in an ad-hoc manner." Ad hocism is a big problem and cause for limping back in many areas. But that can't cloud the dynamism people have in the region.

Another important D-factor for South Asia is the Diaspora. The South Asians are now vibrant and booming in many parts of the world. An estimated 70 million people of South Asian origin are now living around the world. With 10 million more joining the Diaspora each year, their pool of wealth is increasing (Asia One Business, 2013). They are becoming politically powerful in their adopted home countries. The people of South Asian origin are not only becoming important in the places they are living in but are also sending remittances to the countries of their origin. From its Diaspora, India earns most remittances in the world and Bangladesh ranks the fifth. Sri Lankan, Pakistani, Nepali Diaspora are also contributing to their national exchequers. At the point of need, this Diaspora can add human capital to their countries by a reverse brain drain. "While it may not act as a "demographic dividend" at this moment given the lack of economic opportunities, the growing South Asian Diaspora and its economic muscle will also prove the other side of the story. If federalism, democracy, and inclusive governance get established in South Asia, the youth bulge then will become the greatest asset for the 
region. More importantly, the youth does not carry the historical baggage of partition and the horrors of social and political differences. With a positive approach, this generation can be easily molded to ensure South Asia aspires to become another European Union" (Chandran, 2013).

For creativity and development, Diversity is considered to be vital. South Asia has a diverse religious, linguistic, ethnic and geographic kaleidoscope. Diversity in people in the region has brought diversity to their cultures too. Moreover, diverse geography spreading from the great Himalaya to the Indian Ocean, from Afghan rugged land to the Bay of Bengal near Yangon in Myanmar brings such a big landscape for making life colorful and beautiful. On the other side, diversity has its share of problems too. But in South Asia, the movement and interaction of people and the flow of culture from one part to another from the beginning of Indus civilization have threaded them together.

Economic Prospect and Geo-economic Importance: There is no way to miss the point. South Asia now houses some of the fastest growing economies in the world. Individually most of the countries in the region are rising, though not equally. While India is showing all signs of going ahead faster, Bangladesh, Sri Lanka are displaying that they can march ahead too. Presently, South Asia region has an economy of more than US\$ 2.5 trillion. Though the 2008 financial crisis dragged down Indian economic growth for a while, it seems have bounced back. With the assumption of power by a new government in 2014, India is developing into an investment friendly open-market economy. Factors like low dependency ratio, healthy savings and investment rates, and increasing integration into the global economy also make India's future promise more genuine. Not only that, Bangladesh, Sri Lanka, Bhutan have been growing over six percent annually. Together with their growing economy and rising purchasing power of an expanding middle class, South Asia becomes a big market for trade and hence investment destination. Likewise, its physical closeness to South East Asia, China, and Middle East makes South Asia geoeconomically important. In addition, the military power of India and Pakistan and peacekeeping experience of Bangladesh give the region added weight in any future context. Brining Myanmar within the South Asian regional frame, the bullishness on the future of South Asia gets strengthened further.

Strengthening Democracy and Reduction of Intra-State Conflict: A process is on for establishing and strengthening democracy in South Asia. "Compared with the 1980s and 1990s, South Asia is more democratic today. Authoritarian and monarchical regimes in the region have paved the way for democratic regimes, howsoever limited they are" (Chandran, 2013). Indeed, the people of South Asia have strongly demonstrated their preference for democracy, especially in countries either plagued by political instability 
or under military rule. Moreover, the peaceful transition of power through elections in 2013 in Pakistan and Myanmar's effort to form multiparty democracy are some of the heartening examples. Strengthening of democracy too has been happening from the reduction in the intra-state conflicts in Nepal and Sri Lanka.

The point is; popular democratic elections create a festive environment in all the countries in the region. Exercising the right to vote in elections is "not merely about establishing procedural democracy. They mean that the government is accountable to the people. While a civil-military imbalance still exists in some states, the hold of the latter over the former is slowly breaking up. Governments are becoming accountable, and this is great news for the future of South Asia" (Chandran, 2013). In the changing context, the South Asian people can aspire to have liberal democratic states with three key qualities: decisive and determined in its action governed by the rule of law and accountable to the people (Das, 2012). ${ }^{4}$ This may lay down the ground for a cohesive South Asia pursuing the goal of prosperous future of the people via regional collectivism.

Soft Power and IT Power: South Asia's great power is inclusiveness. Although it could be a tall claim that South Asia stands high with many soft powers, claiming them not at all, however, would not reflect the reality either. Joseph Nye of Harvard University has developed the concept of Soft Power to describe the ability to attract and co-opt rather than coerce, use force or give money as a means of persuasion to fall in line to attain some objectives. He coined the term in the 1990 book, Bound to Lead: The Changing Nature of American Power. In view of Nye, power is the ability to affect the behaviour of others to achieve the outcomes one wants. A country's soft power, according to him, rests on three resources: "its culture (in places where it is attractive to others), its political values (when it lives up to them at home and abroad), and its foreign policies (when others see them as legitimate and having moral authority" (Nye, 2011: p.84).

On these, India stands much ahead of others individually in South Asia. As Funabashi (2104) argues, "India possesses the soft power represented by its democracy, English-language capabilities of its people and global media - though in some cases they remain latent soft power. But sooner or later this soft power will elevate India from its current status as a regional power to that of a global power." The common axiom is a rising tide lifts all boats in the river. So, the Indian rise should benefit them all in the region, not just through the trickle down effects but by wilful cooperation and partnering together. However, India should be prepared to play a constructive role so that it can become a relying force for all to go forward to a common future. 
Can information technology (IT) be considered a soft power of South Asian dominance? Nye's interpretation of soft power seems to qualify that to be so. Practically, IT seems to have become a cultural element through which the South Asian brains have brought "VOWs" from others - their attention and admiration. IT knowledge is such a power that has changed the perception of the world on India in particular. The people of the region should be happy to take pride on that the IT engineers of Bangladesh, Sri Lanka, and Pakistan are also promising to come better off. So, to reinforce - it is a power, a weapon to win and not to kill. This can prove to be the greatest soft power for the future promise of South Asia.

\subsection{Positioning South Asia into the 21st Century World Order}

In the 21st century, the position of South Asia in the global order will be determined by the fact that how quickly the region can bring a change in economic fortune of the people. Going by the economic trend, South Asia will be much richer economy by 2030 . This may also coincide with the surpassing of Japan's GDP by India. That looks to a bit earlier than the timeframe projected by Bill Gates when he says that there will be "almost no poor countries by 2035 ", and that child mortality rates in the poorest nations will plummet to the same levels as in the US and UK in 1980 (Bennett and Marcinek, 2014). By then, Bangladesh is projected to be in the top twenty economies in the world. Although Pakistan had a sad history of false dawns and dashed hopes, it still holds the hope for another dawn. The potentials for Sri Lanka to emerge as the Singapore of South Asia can't be ruled out. Similarly, Myanmar, with its huge natural resources and their proper utilization, should add the regional prospects further.

However, the biggest challenge for South Asia will be to attain that level with relative competitiveness in the economies within and outside the region. The Global Competitiveness Report 2013-14 (GCR) of the World economic Forum identifies three broad areas from where the competitiveness of an economy is generated (Figure 1). These are:

- Factor-driven: Based on the factor endowments, for examples unskilled labour and natural resources. The developing countries try to build their capacity and competitiveness on their factors in abundance. Industrial competitiveness of most of the South Asian economies is still arising from factor-driven manufacturing base.

- Efficiency-driven: Based on developing more efficient production processes and increasing the quality of products to account for rising wages. This seems to be the logical push from the first stage of competitiveness development. In South Asia, few industries have graduated to efficiency-driven level. 
- Innovative-driven: Based on the capacity to invent, innovate and develop new and unique products. This blunts the impact of high wages of labour for the businesses. The innovation-driven competitiveness shows the maturity of a particular economy. South Asia can list a very few items like IT sector of India, micro-finance management in Bangladesh, etc. that have fairly reached this phase.

Figure 1: The Global Competitiveness Index Framework

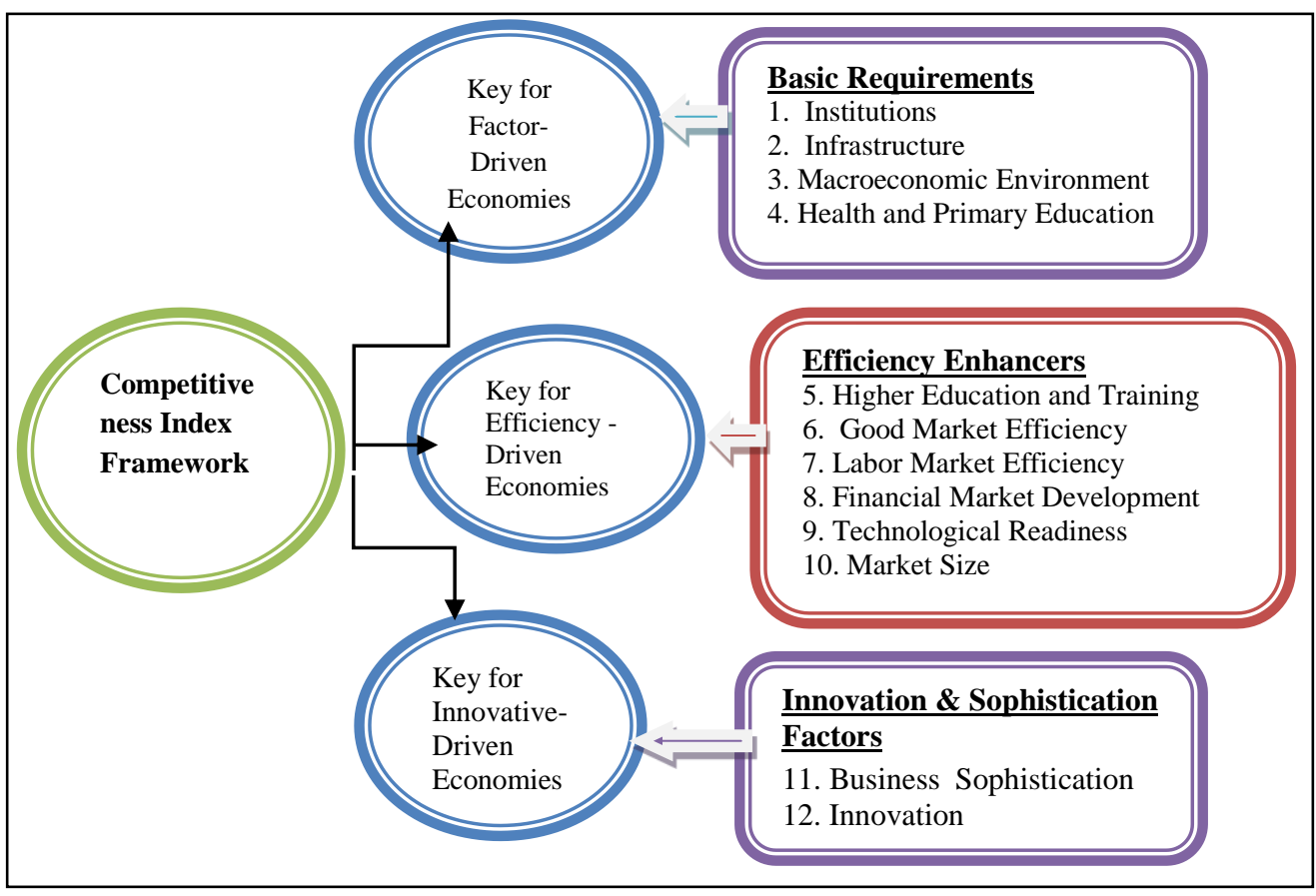

Source: Adopted World Economic Forum, GCR 2013-14

However, there are some pockets of developments that promise that South Asia will climb the ladder of competitiveness as qualitative, and quantitative developments continue to take place side by side. Nevertheless, we must not be blind to the domestic obstacles they have in doing business in their respective economies. The three largest South Asian countries, Pakistan, Bangladesh, and India place 110th, 130th and 134th respectively in the World Bank's "ease of doing business rankings". Sri Lanka tops the list among them by holding the 85th position. "In order to sustain the growth, physical infrastructure will need to be prioritized. In South Asia, education and employment will 
need to be found to stave off possible socio-political unrest among the booming youth population" (Lehmann, 2012).

Leaving the economic promise behind, all round development of a country also depends on 4Ds - Democracy, Demography, Diversity, and Discipline. We have discussed that South Asia has ample of the demography and diversity. Their overall record on democracy is improving, but all countries here suffer from a common cultural lacuna - their people lack discipline. Let us have a look at China and assess its position with respect to these qualitative variables. China has diversity and its people to a large extent obey the dictates of the government and employers. But its demography is deteriorating, and democracy as a method of governance and change of power is not practiced at all. So if China can do an economic miracle without democracy, can South Asia do that without discipline? Possibly, not. That's because at the initial stages of development, or at pre-take-off and take-off stages of Rostow Model, ${ }^{5}$ a country seems to require more of the discipline than democracy. But when it matures, and age of mass consumption begins, democracy becomes a paramount requirement. South Asia's present minor edge in democracy and institutions should be supported and complemented by a disciplined work force and more democratic governance. These can quickly address many of the existing problems in South Asia.

In the end, in contrast to the present South Asia, which is often associated with poverty and backwardness, there are promises that the pendulum will be swinging to the opposite with its image of improving prosperity and success. Besides, "global developments such as China's rise, and the American rebalancing in the Asia Pacific and its implications for Southeast Asia may provide an opportunity for South Asia to link up with its prosperous neighboring regions "(Chandran, 2013). Furthermore, the strategic depth of the South Asian emerges from the size of the economy, market, and huge diverse geographic area. A promise of growth on the base of $\$ 2.5$ trillion economy, 1650 million population on a space of 5.14 million square kilometers can't be ignored when they become united for their common betterment.

\subsection{Conclusion}

The vision of a South Asian to send poverty to the museum through economic progress has raised hope of empowerment of marginalized people in the region and beyond. A process of gradual democratization and people's yearn for more democratic governance side by side the growth of the middle class signaling the change South Asia. With the changing political scenario, some people are willing to break free of the barriers set by the states and transform the economic landscape of South Asia. These 
developments could be directed to further the betterment of people if the countries of the region can offer application-oriented vocational education to a broad segment of people to help them join the production process and become more productive. An important question in this regard is: will the governments choose a path for economic and social development at domestic fronts and can they check any negative strains within that have the potentials to spillover and affect the positive growth in the region?

While the opportunities are immense for South Asia's common future in the 21st century, so are the challenges to convert the potential into a promise. The biggest of them is to develop a meaningful bilateral relationship between India and Pakistan which is still dogged by distrust and based on the zero-sum game. Secondly, the establishment of democratic, accountable and inclusive governments in the South Asian countries has still remained a big ask. Though India has been practicing a more mature democracy, it has to overcome some of the limitations to make it more functional one. Moreover, India, as the largest and more stable country in the region, will have to play a responsible role, perhaps even disproportionately, to increase the cooperative bond and link within the region. Progress on these fronts may ensure that South Asia becomes a powerful bridge between Southeast Asia, China, Central Asia and the Middle East. An economically vibrant Africa will further enhance the positional advantage of South Asia.

In the meanwhile, South Asia needs to develop as a single zone of peace featuring rich history, ethnic and cultural diversity. In a common voice, they have to advocate peaceful and common development, safeguard international justice, and make contributions to humanity. Nonetheless, they should not follow the West in toto in their quest for development, forgetting their core cultural and social values which have been developed for thousands of years as parts of civilization. These values are based on beliefs, faiths, cooperation, tolerance to others opinion, the spirit of coexistence, helping the needy, and so on. In the development process, some nations have shown that economic elevation is a matter of generation. But if development is attained at the cost of basic values of the civilization, then that could be a recipe for disaster. If the countries unit for a common and collective betterment, the chance is there that South Asia will make a strong place in the $21^{\text {st }}$ century. That will ensure the region a better place in the emerging global order. But it's not automatic. To realize this potential, they have to step out together without much delay. Furthermore, the effort to build that common future through SAARC does not seem to be enough. They need to do something more. 


\section{Endnotes}

1. The 2008 financial crisis, also known as the Global Financial Crisis and, is viewed by many economists to have been the worst financial crisis since the Great Depression of the 1930s. It began from the melt down of the real estate sector in the United States soon after the "housing bubble" that reached the peak in 2006. "Subprime" leading and "adjustable-rate mortgage" are considered to have played a vital role in setting on the crisis in motion and aggravate it. Several major US institutions either failed, were acquired under duress or were subject to government takeover due to this crisis. These included Lehman Brothers, Citigroup, AIG, Merrill Lynch, Freddie Mac, and Fannie Mae. The fallout of crisis got a global dimension as the economic and financial repercussions were felt all over the world.

2. An ILO report Global Employment Trends for Youth of August 2010 puts that Youth employment to population ratio in South Asia was at 8.6 percent, and youth unemployment rate 10 percent.

3. In the CPI 2014, Bhutan has been listed as the least corrupt country in South Asia and is ranked at 30 place. India (85), Sri Lanka (85), Nepal (126), Pakistan (126) and Bangladesh (145) followed. Meanwhile, Myanmar held 157th rank, figuring better than Afghanistan (172 rank) which was the world's 3rd on the most corrupt country list, just ahead of Sudan, North Korea, and Somalia.

4. Gurcharan Das in his book India Grows at Night discusses the notion of a strong state for India. His view effectively offers an option for all the states in South Asia, as well. In contrast to the authoritarian regimes of Stalin, Mao and Hitler, he opted for the views of the 18th-century thinkers of the US, who gave the idea of strong, yet liberal democratic state. Understandably, this view of government and governance should be applicable to all of the countries in South Asia for their progress and prosperity.

5. In 1960 American economist Walt Whitman Rostow postulated the Rostovian structuralist model of growth. The model argues that economic growth occurs in five basic stages, viz. traditional society, preconditions for take-off, take-off, drive to maturity and age of high mass consumption, of varying length.

\section{References}

Alkire, S. \& Santosh, M. E. (2010). Multidimensional Poverty Index: Oxford Poverty and Human Development Index - OPHD. The University of Oxford: England. (July).

Das, S. G. (2012). India Grows at Night. Penguin Global: Delhi. (December).

Funabashi, Y. (2014). Build strong Japan-India ties without taking aim at China. The Japan Times, (August 14) 
20 | FOCUS: Journal of International Business, Vol. 2, Issue 1

Ghosh, P. S. (1989). Cooperation and Conflict in South Asia. Technical Publications: Delhi, India.

International Labour Organisation (ILO). (2010). Global Employment Trends for Youth. Geneva. (August).

McLeod, J. (2002). The History of India. Greenwood Publishing Group, Westport: USA.

Nakayma, C. (2014). Building global support for a new economic balance. The Japan Times, (12 August).

Nye, J. S. (2011). The Future of Power. Public Affairs: New York.

Pattanaik, S. S. (2011). Moving Beyond the Rhetoric of Cooperation. In Smruity S. Pattanaik (ed). South Asia - Envisioning A Regional Future, (Institute of Defence Studies and Analysis), New Delhi. pp. XVII-XXVII.

Transparency International. (2014). The Corruption Perception Index 2014. Transparency International, Berlin.

United Nations Statistics Division. (2013). Composition of macro geographical (continental) regions, geographical sub-regions, and selected economic and other groupings, UN: New York. (October 31).

World Bank. (2014). World Development Indicators 2014. Washington D.C.

World Economic Forum. (2013). The Global Competitiveness Report 2013-14. Geneva.

\section{Web References}

Asia One Business. (2013). Remittances to South Asia boost size of middle class. (Oct. 13). (Retrieved Jan. 20,2014).http://business.asiaone.com/news/remittances-south-asiaboost-size-middle-class\#sthash.2ovB3ywD.dpuf

Bennett, S. \& Marcinek, L. (2014). Bill Gates Sees Almost No Poor Countries Left by 2035. (Bloomberg, January 22).http://www.bloomberg.com/news/2014-01-21/bill-gatessees-no-poor-countries-left-by- 2035-in-annual-letter.html 
Cabraal, A. N. (2002). Our Common Future: South Asia. (Retrieved Jan. 20, 2014), http://www.island.lk/2002/01/13/featur04.html

Chandran, D. S. (2013). A common future. The Friday Times. XXV(33). (Sep 27-Oct 3) http://www.thefridaytimes.com/beta3/tft/article.php?issue=20130927\&page=9c;

(Retrieved Jan.20,2014).

Dhakan, A. A. (2014). Jump in Pakistan's poverty level. The Dawn. (Retrieved Jan. 12, 2014). http://www.dawn.com/news/794822/jump-in-pakistans-poverty-level

Index Mundi (http://www.indexmundi.com/burma/gdp_real_growth_rate.html)

Lehmann, J. P. (2013). The Asian 21st Century: Keys for continued growth. IMD (June). (Retrieved Jan. 20,2014). http://www.imd.org/research/challenges/TC050-10.cfm

Trading Economics, (http://www.tradingeconomics.com/myanmar/gdp)

Transform - European Network for Alternative Thinking and Dialogue, "Hegemony and Multipolarity: World Orders in the 21st Century," 2012 (Retrieved Jan. 20,2014).http://transform- network.net/calendar/ archive-2012/news/detail/ Calendar/hegemony-and-multipolarity-world- orders- in-the-21st-century.html

United Nations. (2015). History of the United Nations, (retrieved 15 April, 2015), http://www.un.org/en/aboutun/history/

World Bank. (2013). Doing Business Data, Economy Ranking. Washington, D.C. (Retrieved December 25, 2014). http://www.doingbusiness.org/rankings. 